\title{
Sperm Protein Associated With the Nucleus on the X Chromosome E
}

National Cancer Institute

\section{Source}

National Cancer Institute. Sperm Protein Associated With the Nucleus on the X

Chromosome E. NCI Thesaurus. Code C92982.

Sperm protein associated with the nucleus on the $\mathrm{X}$ chromosome $\mathrm{E}(97 \mathrm{aa}, \sim 11 \mathrm{kDa}$ ) is

encoded by the human SPANXE gene. This protein may be involved in sperm maturation. 